\title{
A NEW SPECIES OF CALISIUS.
}

BY DR. E. BERGROTH, TURTOLA, FINLAND.

Calisius annulicomis, n. sp.

Ovatus ( $q$ ), fuscus, pronoto fusco-nigro, scutello subtestaceo, medio vittis duabus albis antrorsum leviter convergentibus, antice arcuato-conjunctis, postice extrorsum curvatis et latera attingentibus signato, inter has vittas et elevationem basalem nigram fuscoconspurcato, carina media nigra, medio late albo-interrupta, abdomine magna parte obscure rufescente, subtus latera versus parce albo-granulato, antennis fuscis, articulo tertio (ima basi excepta) flavo, articulo quarto nigro, pedibus sordide flavidis, femoribus (ima basi et summo apice exceptis) fuscis. Caput pronoto distincte brevius, antennis capiti subaeque longis, articulo secundo primo crassiore et paullo longiore, tertio secundo fere dimidio longiore, quarto tertio sat multo longiore et crassiore. Pronotum lateribus rectis, irregulariter nigro-spinulosis, medio vix sinuatis insigne, lobo postico carinis sex instructo, duabus mediis antrorsum leviter convergentibus, usque in lobum anticum extensis, carinis subsequentibus in parte basali levius, deinde fortiter convergentibus et usque ad apicem carinarum mediarum extensis, cum his angulum acutum formantibus, carinis extimis prope marginem lateralem sitis. Carina media scutelli granulata. Margo lateralis superior segmentorum connexivi granulis tribus perminutis, margo lateralis inferior granis tribus majoribus albis instructi. Long. o $4 \mathrm{~mm}$.

Tasmania (Launcestown, J. J. Walker). Mus. Brit.

This remarkable species is by many characters very distinct from $C$. interveniens Bergr., the only Australian species hitherto known.

\section{THE NORTH AMERICAN SPECIES OF THE GENERA} ARTHROPEAS AND ARTHROCERAS.

BY CHARLES W. JOHNSON, BOSTON, MASS.

The species Arthropeas leptis Osten Sacken seems to be the cause of some confusion in these two genera. This is probably due to the comparative scarcity of material, to an oversight in Aldrich's Catalogue, and to the fact that Osten Sacken in describing the species and referring to a number of minor characters wherein it differs from the typical Arthropeas failed to mention the most important feature - the absence of spurs on the anterior tibiæ. This character, however, he mentions in 1882 (Berl. Ent. Zeits., XXVI, 365), as follows: "In the notes to my Catal. N. Am. Dipt., 1878 (p. 223), an insect is described which I referred provisionally to the genus Arthropeas. It has the body of a Leptid (Symphoromyia), with the antennæ of a Cœnomyia. It will probably form a new 
genus because, besides the differences in the venation noticed by me in the description, it has no spurs on the front tibiæ, while such spurs are distinct in Arthropeas siberica."

In 1886 Dr. Williston erected the genus Arthroceras (Ent. Americana, II, 107), based chiefly on the character above mentioned with $A$. pollinosum (a new species), and $A$. leptis $\mathrm{O}$. S. as the types. That A.leptis belonged to the genus Arthroceras was recognized by Coquillett in determining the species for Mrs. Slosson's list of Mt. Washington insects (Ent. News. VI, 6, 1895).

The two species may be separated by the following table:

Thorax unicolor, yellowish pollinose; halteres yellow. Colorado, Washington. pollinosum Will. Thorax blackish, with two yellowish pollinose stripes; halteres brown. White Mts., N. H................. leptis O. S.

Both species seem to be confined to the Canadian zone. The former I have received from Clear Creek, Col., May 20, 1891 (Oslar); Happy Hollow and Little Beaver, Col., July 14 and 19 (Gillett). The latter has only been taken in New Hampshire, White Mts., "woods and alpine" (E. P. Austin); "Alpine region of Mt. Washington, at or above 5,500 ft." (Mrs. Slosson); "near summit," Mt. Washington, July 25, 1875 (Dr. Geo. Dimmock); Mt. Washington, July 7, 1909 (F. A. Sherriff); Base Station, Mt. Washington, July 30, 1912 (F. W. Dodge).

The species of the genus Arthropeas are likewise comparatively rare, and also seem to be confined to the Canadian zone. The species may be tabulated as follows:

Anal cell closed; wings distinctly banded; length,

$8-9 \mathrm{~mm} . . . \ldots \ldots \ldots \ldots \ldots \ldots \ldots . \ldots \ldots$. . . . . . . . . . . . .

Anal cell narrowly open; wings not banded; length,

$12-14 \mathrm{~mm}$.......................... magna, n. sp. Arthropeas americana Loew.

The following brief description is given chiefly as a comparative one to Say's Xylophagus fasciatus:

Thorax black, covered with a yellowish pollen, leaving three wide black vittæ; scutellum and metanotum black; abdomen yellow, basal half of the first to fourth segments black, the remaining segments yellow; halteres entirely yellow; legs yellow, outer half of the tarsi brown; apical third of the wing smoky black, base of the submarginal and first posterior, tip of the first basal, the entire discal and fourth posterior and outer portion of the fifth posterior cells whitish and forming a wide band across the centre of the wing; the greater portion of the first and second basal cells, base of the fifth posterior and tip of the anal cell and the anal angle smoky black; base of the wing and greater portion of the anal cell whitish. Length, $8.5 \mathrm{~mm}$. 
The following records constitute our present knowledge of its distribution: N. Wisconsin (Loew); Mass. (O. Sacken); Cheshire Harbor, near Mt. Graylock, Mass., June 30 (I. W. Beecroft); Lake Ganoga, North Mt., Pa., 2,300 ft., Aug. 29, 1897 (C. W. Johnson). $X y l o p h a g u s$ fasciatus Say.

"Wing dusky, fasciated; abdomen fasciated. Inhabits Indiana.

"Body dusky; thorax, posterior portion honey-yellow; poisers blackish at tip; wings dusky, a more distinct band on the middle and at the tip; feet honey-yellow; hind tibice blackish; tergum yellow, basal half of the four basal segments black; remaining segments nearly all black. Length over two-fifths of an inch.

"By an accident the head and anterior part of the thorax of this fine specimen were destroyed, but the above description will sufficiently indicate the species. The wing nervures resemble those of the maculatus Fabr."

In the above description by Say, based on an imperfect specimen, I have italicized the parts sliowing discrepancies to Loew's species. The differences are too great to consider them the same; the description of the bands on the wings; "on the middle and at the tip," also does not agree with Say's usual accuracy. The locality, "Indiana," which is entirely in the upper Austral, would also indicate a different species. Say's reference to maculatus, which is a Xylomyia (=Solva Walk.), would indicate a closed fourth posterior cell.

Arthropeas magna, n. sp.

Arthropeas, n. sp.? Townsend.-Trans. Amer. Ent. Soc., XXII, 61,1895 .

$0^{7}$.-Face blackish, covered with a dull yellowish pollen and pile, beard whitish, face with a deep $\wedge$-shaped groove bordering the oral cavity, from which extends a deep groove between the antennæ to the frontal triangle, ocelligerous tubercle black, palpi, proboscis and antennæ yellow. Thorax black, th inly covered with hair (blackish on the dorsum and yellowish on the sides), through which show four dull yellow pollinose stripes, the lateral stripes broad, the middle one narrow, but expanding at the ends and connected at the humeri and post-alar callosities with the lateral stripes, the black areas between the stripes shining behind the suture; pleuræ black, brownish pollinose; scutellum black. Abdomen black, middle and sides shining, first segment with a wide yellow, pollinose, posterior band, almost interrupted in. the middle and expanding until it attains the full width of the segment at the lateral margins; second, third and fourth segments posteriorly margined with a yellow pollinose band, contracted in the middle and at the ends; on the second and third segments the bands are brown in the middle and at the ends, the remaining segments 
yellowish pollinose; venter entireiy yellow. Legs yellow, coxæ blackish, halteres yellow. Wings brownish, slightly darker in the middle and along the fifth longitudinal vein; veins and costal cells yellow, basal half of the marginal cell white, the greater portion of the first and second basal cells noticeably lighter than the rest of the wing. Length, $12 \mathrm{~mm}$.

․ - Face, front and occiput covered with a dense brown pollen, the front about one-fourth the total width of the head, with five grooves above the base of the antennæ, the four outer ones slightly diverging below, above fusing and deflecting towards the ocelli, the middle one obsoletely divided into three smaller ones below the ocelli. The thoracic stripes are more prominent and a brighter yellow than in the male; scutellum velvety-brown, with three transverse ridges. The abdomen is shining and brownish black, with the posterior pollinose bands on the first, second and third segments, broadly interrupted. Length, $14 \mathrm{~mm}$.

Three specimens, Beulah, Manitoba, received from Mr. C. T. Brues. Holotype and allotype in the author's collection. Paratype in the Museum Comparative Zoology, Cambridge, Mass.; "Hill City, So. Dakota" (Townsend).

This interesting species has the thick heavy form of Canomyia, but the generic characters are those of Arthropeas, except that the anal cell is narrowly open. It seems to more clearly show the relationship of the two genera than the other species.

\section{TWO NEW CANADIAN BEES.}

BY T. D. A. COCKERELL, BOULDER, COLORADO.

Sphecodes hudsoni, n. sp.

ㅇ. Length about $7 \mathrm{~mm}$; head and thorax black, legs dark rufo-fuscous, abdomen entirely clear yellowish-ferruginous; head broader than long, face very broad, thinly covered (including the clypeus) with fine pale hair; mandibles bidentate, the apical half dark chestnut-red, the inner tooth short and rounded, about $208 \mu$ from apex of mandible; process of labrum very broad, shallowly depressed or subemarginate in middle; only the first three points of the flagellum remain in the types, but they are dull ferruginous beneath; clypeus strongly punctured; front extremely, densely and minutely punctured in middle, not quite so densely at sides, the punctures are so small as to be hard to see with a hand lens; mesothorax brilliantly shining, with scattered punctures, the median sulcus well marked; pleura, beneath the wings, with a large shining raised area, the pleura below this with fine close rugæ; area of metathorax large, fully $320 \mu$. long, with about 20 coarse rugæ, the lateral ones parallel, radiating, the middle ones 


\section{$2 \mathrm{BHL}$ Biodiversity Heritage Library}

Johnson, Charles Willison. 1913. "The North American species of the genera Arthropeas and Arthroceras." The Canadian entomologist 45, 9-12. https://doi.org/10.4039/Ent459b-1.

View This Item Online: https://www.biodiversitylibrary.org/item/22231

DOI: https://doi.org/10.4039/Ent459b-1

Permalink: https://www.biodiversitylibrary.org/partpdf/27080

\section{Holding Institution}

MBLWHOI Library

\section{Sponsored by}

MBLWHOI Library

\section{Copyright \& Reuse}

Copyright Status: NOT_IN_COPYRIGHT

This document was created from content at the Biodiversity Heritage Library, the world's largest open access digital library for biodiversity literature and archives. Visit BHL at https://www.biodiversitylibrary.org. 